UNIVERSITY OF CHITRAL JOURNAL OF LINGUISTICS AND LITERATURE

VOL. 3 | ISSUE II | JULY - DEC | 2019

\title{
English as a Tool of British Political and Linguistic Imperialism in Chinua Achebe's $A$ Man of the People
}

Naeema Shah

M. Phil Scholar, Sardar Bahadur Khan Women University, Balochistan anzalnashah@gmail.com

\begin{abstract}
The spread of English is considered as a tool of British political and linguistic imperialism in effects of globalization. Kachrus Three Circle model of World Englishes has always played significant role in the categorization of the spread of English. This model is always used as an important tool to critically analyze the distributed circle of English speaking regions in the world where English is dominant over other languages and cultures. In the present study the outer circle from Kachrus model is focused. A Man of the People by Chinua Achebe has been analysed through the lens of Kachrus Three Circle Model of World Englishes. The study finds that the spread of English is basically a tool used for homogenized attack by British imperialism in order to subdue other cultures, politically and linguistically.
\end{abstract}

Keywords: stigmatization, imperialism, concentric, sweeping generalization

\section{Introduction}

The spread of English began in $16^{\text {th }}$ century, when English language became the tool of imperial expension and end up by gaining special place in the world history. This imperial expansion is due to some major reason as we know British Empire,American supremacy,industrial revolution, scientific challenges and the era of technology was introduced in the history of the world.By the $20^{\text {th }}$ century English language won a special position in the history of significant number of countries.In 1985 Kachru developed the Three circle Model of World Englishes which remains the most influential models for grouping the varieties of English in terms of three cocentriccircles:the inner circle(countries including USA,Canada,Australia), the outer circle(countries including where English is used as a second language, colonial regions like india,Ghana,kenya) and the Expanding Circle(in this circle lies those countries where English is used as a foreign language).These circles shows the type of spread,the patterns of acquisition and the functional domains in which English is used across cultures and languages(Kachru,1985,p.12).In this paper the researcher focuses on the social spread of English , used as a tool of British political and linguistic imperialism through the lense of Kachru three circle model in Chinua Achebes novel A Man of the People.A Man of the People is one of the famous work of Chinua Achebe a Nigerian writer.

In this novel the writer used imaginary places like Bori,Uruaa,Anata and Abaga.But what were happened in those imaginative towns, cities and villages resemble the realities and life experiences 
in most of African societies after postcolonialism. The author of the novel of " $A$ man ofthe people" arranged the events in to 13 chapters in his book. Chinua Achebe used chronological order at large extent and flashback in some extent.Chronological order, this refers to the kind of plot in which the events are arranged from the beginning to the end. For example, in the novel, the events were arranged from when chief Nanga pays a visit at Anata his home village (p. 1), to when the army took over the power from corrupt and irresponsible leaders.Through the lense of Kachrus outer circle the research has been done to identify the causes of peoples ignorance towards reality in A Man of the People.

\section{Problem Statement}

The politics of English revolves around many axes. From the seventeenth century onwards,the English began to extend their language over the world. This expansion of language is due to some important factors as the British Empire,the importance of industrial revolution or the the supremacy of America in all over the world. English keeps on expanding through the effects of globalization .Just because of this social spread English won the title of global language. After postcolonialism this political imperialistic social spread has created a condition of ignorance among other local languages. The importance of regional languages have been ignored by the people due to lack of knowledge and inappropriate information. Due to this hygemonic spread of English people are getting more inclined and to value English and English culture instead of their own local languages and culture. Chinua Achebes novel $A$ man of the people clearly shows this ignorance among the people of the state. The politics of English has moulded the ideologies of colonized regions through the imperialistic power of language.

\section{Research Question}

1) Why English language is used as a tool in British political and linguistic imperialism in Africa?

2) How A Man of the People by Chinua Achebe shows condition of ignorance ?

\section{Rational of Research}

The aim of study is to unveil the reasons behind the influence of English in Chinua Achebe's novel A Man Of The People. Present study is based on qualitative research design with focus on interpretative approach through kachrus concentric model of world englishes.

\section{Research Objectives}

To investigate how English was used as a tool of British political imperialism specially in colonized region of Nigeria after independence in A Man of the People by Chinua Achebe.

To uvail British political imperialistic approaches which has created a condition of ignorance among the people of Anata to identify real man of the people.

\section{Delimitations of the Study}


In this research a post colonial novel $A$ Man of the People by Chinua Achebe literary work has been selected. This novel is one of the remarkable workb of Chinua Achebe among others which depicts the ideological,political and linguistic imperialism of of post colonial period after independence of their country.In this research Kachrus three circle model theory of world Englishes is applied to interpret observable outcomes.

\section{Theoratical Framework}

In this study Kachrus Three Circle Model of World Englishes interprets how people of Anata and other villages were unable to realize the reality of Chief Nanga and also identifies the status and importance of English language in the novel. In 1985 Kachru developed the Three circle Model of World Englishes which remains the most influential models for grouping the varieties of English in terms of three cocentriccircles:the inner circle(countries including USA,Canada,Australia), the outer circle(countries including where English is used as a second language,colonial regions like india,Ghana,kenya) and the Expanding Circle(in this circle lies those countries where English is used as a foreign language).These circles shows the type of spread,the patterns of acquisition and the functional domains in which English is used across cultures and languages(Kachru, 1985, p. 12). In this paper the researcher focuses on the social spread of English, used as a tool of British political and linguistic imperialism through the lense of Kachru three circle model in Chinua Achebes novel A Man of the People.

\section{Literature Review}

Kachrus three circle model of world englishes was developed by kachru in 1985, is remain one of the most influencial models for grouping the varieties of English in the world (Mollin, 2006, p. 41).Kachru describe the spread of English in concentric circles, the inner circle(countries including USA,Canada,Australia), the outer circle(countries including where English is used as a second language,colonial regions like india,Ghana,kenya) and the Expanding Circle(in this circle lies those countries where English is used as a foreign language). These circles shows the type of spread,the patterns of acquisition and the functional domains in which English is used across cultures and languages(Kachru,1985,p.12). The foundation for the expansion of English were laid as the British itself expanded between 1600-1900.English and English culture served as atool to strengthen British rule.The result of colonial education policies was the creation of English speaking native.Robert Phillipson(1992) sees the promotion of English as aWestern domination over under developing countries. According to Robert Phillipson,linguistic imperialism takes place within an overarching structure of asymmetrical north/south relation, where languages interlock with other dimensions,cultural,economic and political. (1996:239)."What can be more universal today than commerce, finance and science?"(follick 1934) In the $20^{\text {th }}$ century the spread of English has continued because of the rising influence of the united states, which became the leading capitalist power.English is often learnt because it is the international language of money(Sullivan 1996). 


\section{Research Method}

The researcher has used qualitative research method to analyze the data from different relevant resources.In this research interpretative and descriptive methods are used to generate observable outcomes to interpret solution to the problem.

\section{Critical Discussion}

1. "We are proud to be Africans.Our true leaders are not those intoxicated with their Oxford,Cambridge or Hardvard degrees but those who speak the language of people.Away with the damnable and expensive university education which only alienates an African from his rich and ancient culture and puts him above his people" (p. 3). In this statement a type of dislike has shown towards British educational system. The leader who is against British imperialism is encouraging his people to be proud of their identity and also promoting the ideology to select a person as their leader who speaks the language of people.

2. "My private secretary has B.A from Oxford" (p. 7). Here in this statement Chief Nanga is introducing his private secretary to Odilli by emphasizing her degree from Oxford.Many linguists have the notion that English is the language of elites.By analyzing Mr Nangas position and high officials they all support English language and adopt it as a medium of inter state communicative language.

3. "There was no election at hand,he said,amid laughter.He had not come to beg for votes, it was just a family reunion---pure and simple.He would have preferred not to speak to his own kinsmen in English which was after all a foreign language, but he had learnt from experience that speeches made in vernacular were liable to be distorted and misquoted the press.Also there were some strangers in that audience who did not speak our own tongue and he did not wish to exclude them. They were all citizens of our great country whether they came from the highlands or the lowlands, etc.etc". (p. 8). In this statement the importance of English for Chief Nanga has represented.British linguistic imperialism is appearantly visible through the ideology of people like Chief Nanga.Instead of valuing his own language he is much comfortable and confident while using English language.

4. "It will not take much time, she said,the soup is already made.A small thing but it struck me even as early as this:Mr Nanga always spoke English or pidgin;his children,whom I discovered went to expensive private schools run by European ladies spoke impeccable English,but Mrs Nanga stuck to our own language---with the odd English word thrown in now and again" (p. 19). English language was used as tool of political and linguistic imperialism after $17^{\text {th }}$ century to expand British expension.Education is the only medium through which the purpose of this expansion can be achieved by inculcating English language and culture into the people of different countries.

5. "Very wise,I said.Without it ,said Mr Nanga,they would become English people.Dont you see they hardly speak our language?Ask them something in it and they reply in English .the little one,Micah,called my mother"a dirty ,bush woman” (p. 22). The children of elite 
class can hardly speak their own language,because the originality of their own language has decreased by the imperialistic approach of English.

6. "I had neglected to bring any reading matter with me on my visit to Bori,and the Ministers library turned out to be not quite to my taste.There was a decorative set of an American encyclopaedia, there was She by Rider Haggard,and also Aysha, or the Return of She; then there were a few books by Marie Corelli and Bertha Clay" (p. 23). Although Britain had been the greatest political,economical and industrial power in the world in the $18^{\text {th }}$ century but by the $19^{\text {th }}$ century USA has emerged as an economic and political superpower.All countries were invited to join international organizations and all they need to communicate.It was too expensive to run multilingual operations, so English got dominant place on international stage. This linguistic power affected world regional languages and people feel the need to learn and understand the language of superpowers.

7. “America may not be perfect,he was saying, but don't forget that we are the only powerful country in the entire history of the world,the only one which had the power to conquer others and didn't do it" (p. 26). By the $19^{\text {th }}$ century USA has emerged as an economic and political superpower.American and British still wanted to have their hegemonic control over colonized regions just after giving them independence too.

8. Gold and chain to symbolize wealth (p. 7). English culture is the capitalist culture.According to Kachrus categorization the outer circle which include colonized countries are much affected by the capitalist ideology of English.Elite class follows British capitalist culture to maintain their supremacy and hegemonic control over oppress people.

9. Kidney pie, steak and milk grill to symbolize western culture on food (p. 46). When colonizers from west expand their influence through language and trade they also inject their cuture by imperialistic approach.

10. Chief Nanga to symbolize selfish persons and irresponsible ones. British selects elite people for their own interest then give them all privileges to enjoy their life and live their lives for maintaining English culture and British power no matter how immoral ,dishonest and irresponsible he becomes.

\section{Diction of the novel}

In the novel, A Man of the People the author uses simple language in which it is well understood by his audiences. Furthermore, the author employs the use of PidginEnglish in small extent, for example, “...I go go haskam if he want see you. Wetin be your name?...” (p. 31).

\section{Findings}

1. Why English language is used as a tool in British political and linguistic imperialism in Africa?To investigate how English was used as a tool of British political imperialism specially in colonized region of Nigeria after independence in A Man of the People by Chinua Achebe.To have international recognition to make their language dominant on 
other languages,to get their interest by communicating easily British used English as a toolto have and maintain their supremacy over the world.

2. How A Man of the People by Chinua Achebe shows condition of ignorance ?The purpose of research is to identify the real man of the people. To unvail British political imperialistic approaches which has created a condition of ignorance among the people of Anata to identify real man of the people. A Man of the People is ironic that it is not relevant to the content of the novel as we expected that the novel to be called "a man of the people" should adhere and expect to see the issues risen to be good and support what the title suggests but is contrary different because what are expressed in the content of the book are the evils done by a person whom people tends to call him as A Man of the People but in fact the person do not deserve to be called so. Ignorance is a condition in which someone lacks knowledge or information on something. From the novel the situation was shown as Odili tells us on people of Anata that, “...they were not only ignorant but cynical...”(p. 2 ), they didn't know that Chief Nanga used his position to enrich himself.

\section{Conclusion}

Chinua Achebes novel A Man of the People is very relevant to our current societies, because all things which discussed with in the novel by the author are those found in our current societies especially in African countries. For example, the issue of corruption, ignorance, betrayal, nepotism, hostility, hypocracy, irresponsibility, linguistic imperialism has been discussed by author by using Chief Nanga who tries to bribe Odili by giving him a certain amount of money but Odili rejected so even in our societies the issue of corruption is the big problem because higher leaders tend to practice corruption. Restriction of ignorance is a step towards development. People of Anata did not know that Chief Nanga was an enemy of the people as he used his power to enrich himself and not others. The dominant status of English is visible throughout the novel how English culture and language has captured the colonized region where English has given the status of associate language but in real it has taken superiority over the regional language. The spread of English is basically a homogenized attack by British imperialism specially on those whom are defined by Kachrus in outer circle.

The title of the book of A Man of the People is ironic that it is not relevant to the content of the novel as we expected that the novel to be called "a man of the people" should adhere and expect to see the issues risen to be good and support what the title suggests but is contrary different because what are expressed in the content of the book are the evils done by a person whom people tends to call him as " a man of the people" but in fact the person do not deserve to be called so.

\section{Refrences}

Park, J. S. Y., \& Wee, L. (2009). The three circles redux: A market-theoretic perspective on World Englishes. Applied Linguistics, 30(3), 389-406. 
Hoogvelt, A. (2001). Globalization and the postcolonial world: The new political economy of development. JHU Press.

Dwivedi, V. (2008). Aspects of realism in Chinua Achebe's A Man of the People.

Bowerman, S. A. (2000). Linguistic imperialism in South Africa: the'unassailable'position of english (Doctoral dissertation, University of Cape Town).

Phillipson, R. (2006). Language policy and linguistic imperialism. An introduction to language policy: Theory and method, 346-361.

Schmitz, J. R. (2014)

Looking under Kachru's $(1982,1985)$ three circles model of World Englishes: the hidden reality and current challenges. Revista Brasileira de Linguística Aplicada, 14(2), 373-411. White, R. (1997, December).

Going round in circles: English as an international language and crosscultural capability. In Crosscultural capability conference (Vol. 97).

Spichtinger, D. (2000). The spread of English and its appropriation. na.

\begin{tabular}{|l|l|}
\hline CC @ 2017 by the author. Licensee University of Chitral, Journal of Linguistics \& \\
Literature, Pakistan. This article is an open access article distributed under the \\
terms and conditions of the Creative Commons Attribution (CC BY) \\
(http://creativecommons.org/licenses/by/4.0/).
\end{tabular}

